\title{
Mengembangkan self-esteem siswa melalui model pembelajaran kooperatif tipe TGT (team games tournament)
}

\author{
Developing students' self esteem used TGT (team games tournament) \\ cooperative learning model
}

\author{
Budiman $^{1}$, Alvi Dwi Januar Kusmantara ${ }^{2}$ \\ 1,2 Program studi PJKR, STKIP Pasundan, Cimahi, Jawa Barat, 40513, Indonesia
}

\begin{abstract}
Abstrak
Penelitian ini bertujuan untuk mengetahui pengaruh model pembelajaran kooperatif tipe TGT (team games tournament) terhadap self-esteem siwa di SMA Pasundan Cimahi. Penelitian ini menggunakan metode eksperimen dengan desain The Randomized pre-testposttest Control Group Design. Sampel pada penelitian ini yaitu siswa kelas XI MIPA 1 yang berjumlah 26 orang sebagai kelas eksperimen yang menggunakan model pembelajaran kooperatif tipe Team Games Tournament dan siswa kelas XI MIPA 2 yang berjumlah 26 orang sebagai kelas kontrol menggunakan model pembelajaran konvensional (direct instruction). Instrumen yang digunakan menggunakan angket yang berjumlah 92 pernyataan. Dari analisis data yang didapat hasil t hitung untuk kelas eksperimen sebesar 5,166 lebih besar dari $t$ tabel yaitu sebesar 2,060 yang artinya terdapat pengaruh yang signifikan dari model pembelajaran kooperatif tipe Team Games Tournament untuk peningkatan self-esteem siswa yang berarti hipotesis diterima. Sedangkan t hitung yang didapat dari kelas kontrol sebesar 2,156 lebih besar dari t tabel yaitu sebesar 2,060 yang artinya terdapat pengaruh yang signifikan dari model pembelajaran konvensional (direct instruction) untuk peningkatan self esteem siswa yang berarti hipotesis ditolak.
\end{abstract}

Kata kunci: self-esteem, model pembelajaran kooperatif tipe team games tournament.

\begin{abstract}
This study aims to determine the effect of the Team Games Tournament cooperative learning model for increasing self-esteem of students in Pasundan Cimahi High School. This study used quantitative experimental research methods with the design of the Randomized pre-test-posttest Control Group Design. The sample in this study were 26 students of MIPA 1 class XI as an experimental class using Team Games Tournament cooperative learning model and 26 students of MIPA 2 class XI as a control class using conventional learning models (direct instruction). The instrument used was a questionnaire of 92 statements. Data analisis showed the result of $t$ count for the experimental class amounted to 5.166 greater than t table that is equal to 2.060, which means there is a significant influence of the type of Team Games Tournament cooperative learning model for increasing students' self esteem. Therefore, the hypotesis is accepted. While t arithmetic obtained from the control class of 2.156 is greater than t table that is equal to 2.060, which means there is a significant influence from the conventional learning model (direct instruction) to increase student self-esteem. Therefore, the hypothesis is rejected
\end{abstract}

Keywords: self esteem, team games tournament type, cooperative learning model. 


\section{PENDAHULUAN}

Pendidikan jasmani pada dasarnya merupakan bagian yang tidak terpisahkan dari sistem pendidikan secara keseluruhan (Bangun, 2012; Nugraha, 2015: Agusni 2017). Pendidikan jasmani tidak hanya mengembangkan keterampilan gerak (Kalaja \& Digelidis, 2012) akan tetapi juga mengembangkan kemampuan pengetahuan, sikap maupun sosial siswa (Youness, 2016). Sejalan dengan itu, Suherman (2009, hlm. 7) mengemukakan bahwa tujuan pendidikan jasmani terdiri dari empat katagori yaitu: 1) perkembangan fisik; 2) perkembangan gerak; 3) perkembangan mental; 4) perkembangan sosial. Dengan demikian pendidikan jasmani yaitu suatu proses pembelajaran melalui aktivitas jasmani yang didesain untuk mengembangkan kemampuan siswa secara holistik.

Adapun salah satu aspek kemampuan afektif yang harus dimiliki siswa adalah self-esteem (Verdianingsih, 2017). Self-esteem merupakan suatu evaluasi positif dan negatif terhadap dirinya sendiri (Srisayekti \& Setiady, 2015). Sikap tersebut dipandang sebagai salah satu aspek penting yang harus dimiliki peserta didik. Sebagaimana penjelasan Lutan (2003, hlm. 8) mengemukakan self-esteem bagi seseorang ibarat fondasi sebuah bangunan rumah. Utari (2007) juga mengatakan bahwa rendahnya self-esteem siswa dapat memperendah hasrat belajar, mengaburkan fokus pikiran dan enggan mengambil resiko. Namun apabila siswa memiliki selfesteem yang positif maka akan membangun pondasi yang kokoh untuk kesuksesan belajar.

Salah satu model pembelajaran yang perlu dipilih dan diterapkan dalam mengembangkan self-esteem siswa adalah model pembelajaran kooperatif tipe TGT (team games tournament). Slavin (2010, hlm. 4) menyatakan bahwa pembelajaran kooperatif merujuk pada kegiatan belajar siswa dalam kelompok untuk bekerja sama mempelajari materi pelajaran. Kemudian Slavin (2015) menyatakan bahwa tipe TGT merupakan prosedur pembelajaran yang memberikan kesempatan kepada kelompok untuk berkompetisi dengan kelompok lain sehingga siswa bergairah belajar. Dengan adanya games dan turnamen yang menjadi karakteristik TGT (team games tournament) membuat siswa antusias selama proses pembelajaran karena siswa ingin membuktikan bahwa dirinya mampu menjadi yang terbaik (Thalita dkk. 2019). Kemudian melalui pembelajaran kooperatif siswa dapat belajar tanggung jawab dalam bentuk kegiatan sosial seperti membuat keputusan dan membangun kepercayaan pada diri sendiri dan tim (Robingatin, 2012). Dengan adanya penilaian sikap positif dalam proses pembelajaran dengan model kooperatif tipe TGT (team games tournament) maka diharapkan dapat mengembangkan self-esteem siswa.

Berdasarkan urain di atas, tujuan penelitian ini untuk mengetahui pengaruh model pembelajaran kooperatif tipe TGT (team games tournament) terhadap self-esteem siwa. 


\section{METODE}

Metode yang digunakan dalam penelitian ini yaitu eksperimen. Dengan desain The Randomized Pretest-Posttest Control Group Design. Populasi yang digunakan dalam penelitian ini adalah siswa kelas XI MIPA SMA Pasundan 2 Cimahi sebanyak 78 orang. Sampel yang akan digunakan yaitu kelas XI MIPA 1 sebanyak 26 orang dengan rincian 8 siswa putra dan 18 siswa putri sebagai kelompok eksperimen yang akan menggunakan model pembelajaran kooperatif tipe team games tournament (TGT) dan kelas XI MIPA 2 sebanyak 26 orang dengan rincian 8 siswa putra dan 18 siswa putri sebagai kelompok kontrol yang akan menggunakan model pembelajaran konvensional (direct instruction).

\section{HASIL DAN PEMBAHASAN}

\section{Hasil}

Uji Normalitas

Uji normalitas dimaksudkan untuk mengetahui apakah variabel-variabel dalam penelitian mempunyai sebaran distribusi normal atau tidak. Penghitungan uji normalitas ini menggunakan bantuan program SPSS 25. Hasilnya dapat dilihat pada Tabel 1.

Tabel 1. Uji Tes Normalitas

\begin{tabular}{lccc}
\hline \multicolumn{1}{c}{ Kelas } & Statistic & Df & Sig. \\
\hline Kelas Eksperimen &, 952 & 26 &, 255 \\
Kelas Kontrol &, 944 & 26 &, 171 \\
\hline
\end{tabular}

Pada uji tes normalitas yang dilakukan pada kelompok eksperimen sebesar 0,255 yang artinya data dari hasil tersebut berdistribusi normal karena $0,255>0,05$. Sedangkan pada uji tes normalitas yang dilakukan pada kelompok kontrol mendapat nilai sig. Sebesar 0,171 yang artinya data dari hasil tersebut berdistribusi normal karena $0.171>0,05$.

\section{Uji Homogenitas}

Uji homogenitas adalah pengujian mengenai sama tidaknya variansi-variansi dua buah distribusi atau lebih. Uji homogenitas dimaksudkan untuk memberikan keyakinan bahwa sekumpulan data dalam serangkaian analisis memang berasal dari populasi yang tidak jauh berbeda keragamannya. Jika nilai signifikansi $<0,05$ maka data tidak homogen, sedangkan apabila nilai signifikansi $>0,05$ maka data homogen. Hasil uji homogenitas bisa dilihat pada Tabel 2.

Tabel 2. Uji Homogenitas

\begin{tabular}{|c|c|c|c|}
\hline Levene Statistic & df1 & df2 & Sig. \\
\hline 2,390 & 1 & 50 &, 128 \\
\hline
\end{tabular}


Nilai signifikansi yang didapat pada uji homogenitas di atas adalah sebesar 0,128 yang berarti nilai di atas bersifat sama atau homogen karena nilai sig. 0,128 >0,05.

\section{Paired Samples T Test}

Uji-t digunakan untuk mencari adakah pengaruh yang signifikan antara hasil skor pre-test dan hasil skor posttest pada kelas eksperimen dan kelas kontrol. Uji t digunakan untuk menguji hipotesis yang berbunyi "Terdapat pengaruh yang signifikan antara model pembelajaran kooperatif tipe teams games tournament (TGT) untuk peningkatan self-esteem siswa" dan hipotesis kedua yang berbunyi "Tidak terdapat pengaruh yang signifikan antara model pembelajaran konvensional terhadap peningkatan self-esteem siswa". Apabila hasil $\mathrm{T}$ hitung $>\mathrm{T}$ Tabel dimana $\mathrm{T}$ tabel disini dengan df 25 dan $\alpha=0,05$ yaitu sebesar 2,060 dan apabila nilai signifikansi atau sig.2 (2-Tailed) sebesar $<0,05$ maka dapat disimpulkan bahwa hasil tersebut terdapat perbedaan yang signifikan. Sedangkan apabila hasil hasil $\mathrm{T}_{\text {hitung }}<\mathrm{T}$ Tabel dan nilai signifikansi atau sig.2 (2-Tailed) sebesar > 0,05 maka dapat disimpulkan hasil tersebut tidak terdapat perbedaan yang signifikan. Penghitungan menggunakan uji Paired Samples T Test dengan SPSS versi 25 dapat dilihat pada Tabel 3.

Tabel 3. Paired Samples T Test

\begin{tabular}{llccc}
\hline \multicolumn{1}{c}{ Kelas } & Df & Thitung $_{\text {con }}$ & T $_{\text {tabel }}$ & Sig. (2-Tailed) \\
\hline Kelas Eksperimen & 25 & 5,166 & 2,060 &, 000 \\
Kelas Kontrol & 25 & 2,156 & 2,060 &, 041 \\
\hline
\end{tabular}

Berdasarkan tabel tersebut didapatkan hasil dari kelompok eksperimen mendapat nilai

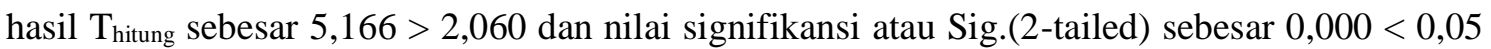
yang artinya terdapat pengaruh yang signifikan dari model pembelajaran kooperatif tipe team games tournament (TGT) untuk peningkatan self-esteem siswa dengan demikian Ho ditolak dan Ha diterima/hipotesis diterima. Sedangkan hasil yang didapatkan dari kelompok kontrol mendapat nilai $\mathrm{T}_{\text {hitung }}$ sebesar 2,156> 2,060 dan mendapat signifikansi atau Sig. (2-Tailed) sebesar 0,041>0,05 yang artinya tidak terdapat pengaruh yang signifikan dari model pembelajaran konvensional (direct instruction) untuk peningkatan self-esteem siswa dengan demikian hipotesis ditolak.

\section{Uji Independent Sample T Test}

Uji independen sample t test digunakan untuk mengetahui apakah terdapat perbedaan rata-rata dua sampel yang tidak berpasangan. Persyaratan pokok dalam uji independen sample $t$ test adalah data berdistribusi normal dan homogen (tidak mutlak). Uji independen sample t test pada penelitian ini untuk menguji hipotesis yang berbunyi "Terdapat perbedaan hasil yang signifikan antara model pembelajaran kooperatif tipe teams games tournament dengan model pembelajaran konvensional terhadap peningkatan self-esteem siswa". 
Apabila hasil signifikansi atau sig.2 (2-Tailed) sebesar $<0,05$ maka dapat disimpulkan bahwa hasil tersebut terdapat perbedaan yang signifikan, sedangkan apabila hasil signifikansi atau sig.2 (2-Tailed) sebesar > 0,05 maka dapat disimpulkan hasil tersebut tidak dapat perbedaan yang signifikan. Hasil Uji independent sample t test bisa dilihat pada Tabel 4.

Tabel 4. Uji independent sample $t$ test

\begin{tabular}{ccccc}
\hline F & Sig. & T & Df & Sig. (2-tailed) \\
\hline 2,390 &, 128 & 5,479 & 50 &, 000 \\
\hline
\end{tabular}

Berdasarkan tabel tersebut didapatkan hasil dari nilai signifikansi atau Sig. (2-Tailed) sebesar $0,000<0,05$ yang berarti Ho ditolak dan Ha diterima. Artinya pada penelitian ini terdapat perbedaan hasil yang signifikan antara model pembelajaran kooperatif tipe team games tournament dengan model pembelajaran konvensional terhadap peningkatan self-esteem siswa dengan demikian hipotesis diterima. Dimana kelas yang menggunakan model pembelajaran kooperatif tipe team games tournament (TGT) mendapat peningkatan yang lebih besar dibanding siswa yang menggunakan model pembelajaran konvensional.

\section{Pembahasan}

Berdasarkan penghitungan yang telah dilakukan didapatkan hasil bahwa terdapat peningkatan yang signifikan dari model pembelajaran team games tournament (TGT) untuk peningkatan self-esteem siswa MIPA 1 SMA Pasundan 2 Cimahi. Pemberian perlakuan pada penelitian ini yaitu sebanyak 5 pertemuan dengan 1 pertemuan dengan 3 jam pelajaran di tiap minggu materi yang diberikan yaitu permainan bola besar antara lain basket, voli dan sepak bola.

Multyaningsih (2014, hlm. 244) menyatakan bahwa model pembelajaran TGT (team games tournament) memberikan peluang kepada siswa untuk belajar lebih rileks disamping menumbuhkan tanggungjawab, kerjasama, persaingan sehat, dan keterlibatan belajar. Kemudian Brewer (dalam Robingatin, 2012) juga berpendapat bahwa pengembangan self-esteem anak dapat dilakukan melalui pembelajaran yang berbasis pada kooperatif, karena melalui pembelajaran kooperatif anak dapat memperkirakan tanggung jawab dalam bentuk kegiatan sosial seperti membuat keputusan dan membangun kepercayaan pada tim. Dengan demikian, model pembelajaran kooperatif tipe team games tournament membuat peserta didik ikut aktif dan memiliki peranan penting dalam kelompoknya, menumbuhkan kebersamaan dan saling menghargai, serta membuat siswa senang dan bersemangat karena ada kegiatan berupa turnamen dan memiliki sebuah penghargaan bagi kelompok terbaik

Berdasarkan hasil temuan di lapangan pada praktiknya siswa yang menggunakan model pembelajaran kooperatif tipe team games tournament pada awalnya terlihat bingung, kaku dan 
hasilnya tidak efisien dikarenakan para siswa baru menjalani model pembelajaran ini, namun ketika di pertemuan kedua dan selanjutnya para siswa sudah mulai mengerti dan terbiasa dengan model pembelajaran yang diterapkan. Hal tersebut terlihat ketika para siswa semakin efektif dalam melakukan tugas gerak yang diberikan dan juga siswa terlihat antusias ketika diberikan games dengan format turnamen dengan adanya reinforcement di akhir turnamen. Dengan ini berarti pemberian model pembelajaran team games tournament (TGT) efektif untuk meningkatkan self-esteem siswa.

Pada siswa dengan kelompok kontrol didapatkan hasil peningkatan yang signifikan dari model pembelajaran konvensional (direct instruction) untuk peningkatan self-esteem siswa. Hal ini dikarenakan para siswa sudah sangat terbiasa menggunakan model pembelajaran konvensional (direct instruction). Berdasarkan fakta temuan di lapangan pada pertemuan pertama para siswa terlihat senang meskipun beberapa gerakan tidak sesuai dengan materi dan ketika diberikan permainan masih banyak siswa yang melakukan permainan tanpa memperhatikan apa yang telah dipelajari. Pada pertemuan kedua setelah dievaluasi dari pertemuan pertama siswa sudah mulai terlihat memperhatikan apa yang telah dipelajari dan siswa sudah mulai fokus terhadap pencapaian tujuan. Pada pertemuan ketiga siswa sudah melakukan melakukan permainan dengan baik dan merasa senang karena dapat melakukan permainan dengan baik. Pada pertemuan keempat dan kelima siswa terlihat sudah merasa bosan ditandai dengan kurang menunjukkan rasa senang saat melakukan pembelajaran terlihat ketika berkurangnya antusiasme siswa saat melakukan tugas gerak yang diberikan. Tetapi pada tes akhir yang diberikan, hasilnya model pembelajaran konvensional (direct instruction) memiliki pengaruh yang signifikan terhadap peningkatan self esteem siswa.

Dari hasil yang didapat antara model pembelajaran Team Games Tournament (TGT) dan model pembelajaran konvensional (direct instruction) keduanya memberikan hasil yang signifikan untuk peningkatan self esteem siswa. Namun berdasarkan hasil penghitungan yang telah dilakukan hasilnya bahwa siswa yang menggunakan model pembelajaran Team Games Tournament mengalami peningkatan signifikan yang lebih besar daripada model pembelajaran konvensional (direct instruction). Karena pada praktiknya model pembelajaran TGT (team games tournament) memberikan siswa kesempatan untuk berperan aktif dan memliki peranan penting pada tiap kelompoknya. Namun pada faktanya penyampaian model pembelajaran TGT (team games tournament) ini harus secara perlahan dikarenakan tidak banyak guru yang menggunakan model pembelajaran ini sehingga siswa harus beradaptasi terlebih dahulu terhadap model pembelajaran ini. 


\section{KESIMPULAN}

1. Terdapat pengaruh yang signifikan dari model pembelajaran kooperatif tipe team games tournament (TGT) terhadap peningkatan self-esteem siswa kelas XI MIPA 1 SMA Pasundan 2 Cimahi sebagai kelas eksperimen.

2. Terdapat pengaruh yang signifikan dari model pembelajaran konvensional terhadap peningkatan self-esteem siswa kelas XI MIPA 2 SMA Pasundan 2 Cimahi sebagai kelas kontrol.

3. Terdapat perbedaan pengaruh yang signifikan antara siswa yang menggunakan model pembelajaran kooperatif tipe team games tournament (TGT) dan model pembelajaran konvensional terhadap peningkatan self-esteem siswa.

\section{DAFTAR PUSTAKA}

Agusni, D (2016). Pengaruh Model Kooperatif Tipe Student Team Achievement Division (STAD) terhadap Keterampilan Chest Pass dalam Pembelajaran Bola Basket di Pasundan 2 Kota Cimahi. Jurnal Olahraga. 2 (2), 39-48.

Bangun, S. Y. (2012). Analisis Tujuan Materi Pelajaran dan Metode Pembelajaran Dalam Pendidikan Jasmani. Jurnal Cerdas Sifa Pendidikan, 01(01), 1-10.

Kalaja, S. P., Jaakkola, T. T., Liukkonen, J. O., \& Digelidis, N. (2012). Development of junior high school students' fundamental movement skills and physical activity in a naturalistic physical education setting. Physical Education and Sport Pedagogy, 17(4), 411-428. https://doi.org/10.1080/17408989.2011.603124

Lutan, Rusli. (2003a). Self esteem; landasan kepribadian, Jakarta; Bagian Proyek

Multyaningsih, Endang. (2014). Metode Penelitian Terapan Bidang Pendidikan. Bandung: Alfabeta

Nugraha, B. (2015). Pendidikan Jasmani Olahraga Usia Dini. Jurnal Pendidikan Anak, 4(1), 557-564. https://doi.org/10.21831/jpa.v4i1.12344

Robingatin. (2012). Pengembangan self esteem melalui pembelajaran kooperatif. Dinamika Ilmu, 12(1), 1-10. https://doi.org/https://doi.org/10.21093/di.v12i1.59

Slavin, R.E. (2010). Cooperative Learning Teori, Riset dan Praktik. Bandung: Nusa Media

Slavin, R.E. (2015). Cooperative Learning Teori, Riset dan Praktik. Bandung: Nusa Media

Srisayekti, W., \& Setiady, D. A. (2015). Harga-diri (Self-esteem) Terancam dan Perilaku Menghindar. Jurnal Psikologi, 42(2), 141. https://doi.org/10.22146/jpsi.7169

Suherman, Adang. (2009a). Revitalisasi Pengajaran dalam Pendidikan Jasmani. Bandung: CV Bintang Worli Artika.

Thalita, A. R., Fitriyani, A. D., \& Nuryani, P. (2019). Penerapan Model Pembelajaran Tgt Untuk Meningkatkan Keaktifan Belajar Siswa Kelas Iv. Jurnal Pendidikan Guru Sekolah Dasar, 4(2), 147-156. https://doi.org/10.17509/jpgsd.v4i2.20543 
Utari, R. (2007). Upaya Sekolah dalam Pembentukan Self-esteem Siswa melalui Pembelajaran. Dalam Dinamika Pendidikan No. 1/Th.IXV/Mei 2007

Verdianingsih, E. (2017). Self-Esteem Dalam Pembelajaran Matematika. Eduscope, 03(02), 815.

Youness, E. A. (2016). Knowledge, Attitudes and Practices of Physical Education Pre-Service and In-Service Teachers Toward Physical Activity Promotion: A Cross-Sectional Study. Journal of Physical Education Research, 3(IV), 64-74. 